\title{
SIZE AND FORM OF PLOTS FOR THE CULTURE OF THE ITALIAN PUMPKIN IN PLASTIC GREENHOUSE
}

\author{
Rodrigo Machado Mello; ${ }^{1}$ Alessandro Dal’Col Lúcio ${ }^{1 *}$; Lindolfo Storck¹; Leandro Homrich \\ Lorentz $^{2}$; Ricardo Howes Carpes ${ }^{3}$; Alexandra Augusti Boligon ${ }^{3}$ \\ ${ }^{1}$ UFSM - Depto. de Fitotecnia, 97105-900 - Santa Maria, RS - Brasil. \\ ${ }^{2}$ UFSM - Programa de Pós-Graduação em Agronomia. \\ ${ }^{3}$ UFSM - Graduando em Agronomia. \\ *Corresponding author <adlucio@smail.ufsm.br>
}

\begin{abstract}
Quality control is the guaranty that experimental error is kept under acceptable levels, and the definition of the proper size and form of experimental plots ensures acurate experimental planning. This paper aims to determine the proper plot size and shape for the culture of the Italian pumpkin in protected environments. Two experiments were set in plastic green house in distinct crop seasons: either Summer-Fall or Winter-Spring season. The experiment comprised eight, 23-m long lines with 20 plants each, and fruit weight was considered the main performance parameter. Estimates of best plots size and shape were obtained by the maximum curvature, variance comparison and Hatheway methods. The plot size and shape varied according to the season and the ideal size and shape, according to the maximum curvature and Hatheway methods, to the Summer-Fall and Winter-Spring seasons, were eight plants $(4 \times$ 2 plot) and four plants $(2 \times 2$ plot $)$, respectively.

Key words: Curcubita pepo, protected environment, experiment planning, quality control
\end{abstract}

\section{TAMANHO E FORMADE PARCELAS PARAACULTURADA ABÓBORAITALIANACULTIVADAEMESTUFAPLÁSTICA}

\begin{abstract}
RESUMO: Na experimentação é de fundamental importância o controle de qualidade, fazendo com que o erro experimental apresente-se em níveis aceitáveis e, uma das formas desse controle, é a definição do tamanho e forma ótimos de parcela, no planejamento experimental. Determinou-se o tamanho e a forma ideais de parcela, para a cultura da abóbora italiana, em experimentos realizados sob ambientes protegidos, avaliando-se o rendimento acumulado da fitomassa dos frutos. Foram conduzidos dois experimentos em estufa plástica, modelo arco pampeano, durante o ano de 2001, em duas épocas de cultivo, um na estação sazonal verão-outono e outro na estação sazonal inverno-primavera. Os experimentos foram constituídos de oito fileiras de $20 \mathrm{~m}$ de comprimento, sendo que, em cada uma delas, foram alocadas 20 plantas. As estimativas do tamanho e da forma de parcela foram obtidas pelos métodos da máxima curvatura, da comparação das variâncias e de Hatheway. As estimativas do tamanho e da forma da parcela variaram conforme a estação sazonal e o tamanho e a forma ideais, segundo os métodos da máxima curvatura e de Hatheway, para as estações sazonais verão-outono e inverno-primavera, foram de oito (quatro no comprimento e duas na largura) e quatro plantas (duas no comprimento e duas na largura), respectivamente. Palavras-chave: Curcubita pepo, ambiente protegido, planejamento de experimentos, controle de qualidade
\end{abstract}

\section{INTRODUCTION}

The italian pumpkin Cucurbita pepo (Cucurbitacea) stands as one of the twelve vegetables with the leading economic value and production in Brazil, being the cultivars Clarita, Clarinda AG-135, Caserta CAC and Caserta BR the most known. Because of the product shortage in the market, producers from the southern-most state Rio Grande do Sul started to cultivate the Italian pumpkin in plastic greenhouses, in periods when the field production is not viable or scarce, as an alternative to increase the profits.
Therefore, the expansion of this crop system and allied research efforts, brought increasing need for reliable research results. To improve the quality of these results it is necessary to reduce experimental error by estimating, for instance, the adequate size and shape of replicates, one of the main problems in experimental design and planning. Researchers often solve this problem empirically, using pragmatical plot sizes or personnal experience to set up the experiment within a given, available area.

Control of experimental error can be accomplished trough the use of concomitant observations, by 
adequate experimental design and ideal replicate size and shapes (Steel et al., 1997). The control of error by experimental design consists in planning the experiment seeking the control of variation that occurs in the experimental area (Zanon \& Storck, 2000). However, the adequate design depends on the culture, number of treatments, size of the experimental units, and environmental conditions. To determine size and shapes of replicates, researchers generally run a blank assay, which is also useful to determine the number of replications, local soil heterogeneity, relative efficiency of a given experimental design, and to predict the outcome of subsequent experiments.

The maximum curvature (Smith, 1938), the modified maximum curvature, the relative information, the multiple regression (Hatheway \& Williams, 1958; Hatheway, 1961), the comparison of variance and the method of Gomes (1984) stand among the most used methods to estimate size and shape of experimental replicates. However, this diversity of methods can hamper the choice of the adequate method to be used for these estimates (Storck, 1979).

Lopes et al. (1998) identified by the maximum curvature method that replicates with less than 18 plants $\left(5.4 \mathrm{~m}^{2}\right)$ set in totally randomized design are the ideal statistical model to study salad-type tomato crops in plastic greenhouses but, in general, these information have been generated specially for big cultures, such as corn (Storck \& Uitdewilligen, 1980; Resende \& Souza Jr., 1997) and soy (Storck et al., 1982). There is still a lack of reliable information regarding vegetable crops, specially those planted in protected environments. This work aims to determinate optimal size and shape of replicates for the study of the Italian pumpkin crop, in protected environment, in two different crop periods.

\section{MATERIAL AND METHODS}

Trials were set up in Santa Maria, RS, Brazil (29 43'23's; 53 45'15' W; altitude $95 \mathrm{~m}$ ). The soil of the experimental area is a Typic Hapludalf. The plastic greenhouse was $24 \mathrm{~m}$ long by $10 \mathrm{~m}$ wide by $2 \mathrm{~m}$ height, 3.5 $\mathrm{m}$ at the ridge. Roof, lateral curtains and laterals and doors were made of low density, $100-\mu \mathrm{m}$ thick, anti-UV treated, polyethylene film (PEBD).

Italian pumpkin seedlings, cultivar Caserta, were produced in Styrofoam trays over metal frames, inside a nursery greenhouse, with plastic cover and wetted by micro-sprinklers. Seedlings were transplanted either in late February (Summer/Fall) or early September (Winter/ Spring), 2001. Plants were cultivated in eight lines of 20 plants, spaced $0.9 \mathrm{~m}$. The rows were set on $0.1-\mathrm{m}$ height by $0.4-\mathrm{m}$ wide beds, covered with $100-\mu \mathrm{m}$ thick, black mulching PEDB.
The soil preparation was done with a revolving hoe, and the chemical fertilization occurred based on the soil analyses results, following official culture recommendations. Irrigation was done by dripping under the mulching; the quantity of irrigation water was defined based on the tension of water in the soil, for each row of plants, and controlled by low-fltbow jet hydrometers. Plants were cultivated in one stem, through vertical raffia strings, supported by steel wires, fastened to the height of the greenhouse's ridge.

Routine cultural practices and phytossanitary treatments were performed after weekly evaluations. The temperature in the interior of the greenhouse was controlled by natural ventilation only, through opening and closing of the lateral curtains. The basic unit (BU) was composed by a plant and resulted in 20 basic units, in each of the eight rows. The plants were identified with labels containing the number of the row and the disposition of the plant inside each row. Fruits harvested in each date were stored in identified plastic bags and weighted. Two types of replicates were planed, with varying size and shape. Each type of plot had X1 width basic unit (rows) and X2 length basic unit (columns), formed by the grouping of contiguous units, in a way that $\mathrm{X} 1 * \mathrm{X} 2$ corresponds to $\mathrm{X}$ size of the replicate in number of basic units. The fourteen types of plots planed (Table 1) are divisors of eight rows and of 20 columns of the trial. Therefore, the number of replicates per plot was limited by the total area of the plastic greenhouse.

For the variable accumulated value of fruit phytomass per plant, fourteen types of plots were planned and the following parameters were established: $\mathrm{N}=160$ / $\mathrm{X}=$ number of replicates with $\mathrm{X}$ basic units (BU) of size; $\mathrm{M}(\mathrm{x})=$ replicate with $\mathrm{X}$ BU of size average; $\mathrm{V}(\mathrm{x})=$ variance between the portions of $\mathrm{X}$ BU of size; $\mathrm{VU}(\mathrm{X})=$ $\mathrm{V}(\mathrm{X}) / \mathrm{X}=$ variance by $\mathrm{BU}$ between the portions of $\mathrm{X} \mathrm{BU}$; $\mathrm{CV}(\mathrm{x})=$ variation coefficient between the $\mathrm{X} \mathrm{BU}$ replicates of size, $\operatorname{VR}(\mathrm{x})$ = reduced variance for a basic unit $-\mathrm{VR}(\mathrm{x})$ $=\mathrm{V}(\mathrm{x}) / \mathrm{X}-$ according to Vallejo \& Mendonza (1992) and Ortiz (1995). Starting from these parameters, the soil "b" heterogeneity index was estimated, according to the empirical relation $\mathrm{VU}(\mathrm{x})=\mathrm{V} 1 / \mathrm{X}$ (Smith, 1938), for the accumulated value of fruit phytomass per plant. The value

Table 1 - Number of basic units (BU) for X1 BU of width and $\mathrm{X} 2 \mathrm{BU}$ of length and size of replicates $(\mathrm{X})$ in number of BU's (between parentesis), for the Italian pumpkin plot culture in plastic greenhouses.

\begin{tabular}{lrrr}
\hline $\mathrm{X} 2$ & $\mathrm{X} 1=1$ & $\mathrm{X} 1=2$ & $\mathrm{X} 1=4$ \\
\hline 1 & $160(\mathrm{X}=1)$ & $8(\mathrm{X}=2)$ & $40(\mathrm{X}=4)$ \\
2 & $80(\mathrm{X}=2)$ & $40(\mathrm{X}=4)$ & $20(\mathrm{X}=8)$ \\
4 & $40(\mathrm{X}=4)$ & $20(\mathrm{X}=8)$ & $10(\mathrm{X}=16)$ \\
5 & $32(\mathrm{X}=5)$ & $16(\mathrm{X}=10)$ & $8(\mathrm{X}=20)$ \\
10 & $16(\mathrm{X}=10)$ & $8(\mathrm{X}=20)$ & - \\
\hline
\end{tabular}


of "b" was estimated by a linear regression coefficient, trough the logarithmic of Smith's equation (1938), weighted by the $\log \mathrm{VU}(\mathrm{x})=\log \mathrm{V} 1-\mathrm{b} \log \mathrm{X}$ of the degrees of freedom.

If the empirical relation proposed by Smith (1938) is precisely adjusted, the function $C V(x)=a / X^{b^{\prime}}$ will also adjust, because $\mathrm{CV}(\mathrm{x})=100 *[\mathrm{~V}(\mathrm{x}) / \mathrm{M}(\mathrm{x})]^{1 / 2}$, being $\mathrm{M}(\mathrm{x})$ a measurement of the plot size in terms of determination of fruit phytomass, because $M(x)$ is the average of a $\mathrm{X}$ plot size determination, that is, $\mathrm{M}(\mathrm{x})=$ $\mathrm{X}^{*} \mathrm{M}(1)$ being $\mathrm{M}(1)$ the average of a $\mathrm{BU}$ replicate (Lessman \& Atkins, 1963). The coefficient b’ measures the association between $\mathrm{CV}(\mathrm{x})$ and the plot size and the estimate of "a" is the estimate of VC(1). By comparisons, the constants "a" and b' from the general equation of $\mathrm{CV}(\mathrm{x})$, transformed in logarithm, are estimated by the equation $\log \{\mathrm{CV}(\mathrm{x})\}=\log (\mathrm{a})-\mathrm{b}{ }^{*} \log (\mathrm{x})$, weighted by the degrees of freedom. After the values of $\mathrm{CV}(\mathrm{x}), \mathrm{VR}(\mathrm{x})$, "a" and soil "b" heterogeneity rate, the optimum plot size was estimated by either the maximum curvature method, the variances comparison method or Hatheway method.

For the maximum curvature method, a graph was established by plotting the coefficient of variation $\mathrm{VC}(\mathrm{x})$ in the coordinate axis and the plot area, in number of BU's, in the abscissa axis. The optimum plot size (Xo), by visual determination, is the point of maximum curvature in the graph.

For the method of comparison of variances, consecutive Bartlett tests, $\alpha=0.05$ (Steel et al., 1997), were run to check the homogeneity of reduced variances for a basic unit $\operatorname{VR}(\mathrm{x})$. After each test in which the variances are considered heterogeneous, the plot with smaller number of BU will be excluded and the Bartlett test repeated among the $\operatorname{VR}(\mathrm{x})$ of the remaining plots. A group of plots with homogeneous $\operatorname{VR}(\mathrm{x})$ is defined, and the plot with the smallest number of BU chosen as optimum plot size.

Hatheway (1961) proposed a method that does not consider the costs of information obtainment, as used by Smith (1938). The method combined the formula of Cochran \& Cox (1968) to determinate the number of repetitions, starting from the relation of Smith (1938). This method considers the coefficient of variation estimated for the replicate of one BU, the foreseen number of replications (r), the soil heterogeneity rate, the values of distribution of " $\mathrm{t}$ " of Student and the minimum significant difference between averages of two treatments, measured by the percentage of the real average (d).

$$
\mathrm{d}^{2}=2\left(\mathrm{t}_{1}+\mathrm{t}_{2}\right)^{2} \mathrm{a}^{2} / \mathrm{r} \mathrm{X}^{\mathrm{b}}
$$

being: $\mathrm{t}_{1}=\mathrm{t}_{\alpha 1(\mathrm{gl})} ; \mathrm{t}_{2}=\mathrm{t}_{\alpha 2(\mathrm{gl}) \text {, }}$ for infinite $\mathrm{df} ; \alpha_{1}=0.05 ; \alpha_{2}=2(1-$ $\mathrm{P}) ; \mathrm{r}=4,8$ and 16 replicates; $\mathrm{a}=$ the estimate of the coefficient of variation of the plots of a BU from log $\mathrm{CV}(\mathrm{x})=\mathrm{a} / \mathrm{X}^{\mathrm{b}} ; \mathrm{b}=$ soil's heterogeneity index from log $\mathrm{VU}(\mathrm{x})=\mathrm{V} 1 / \mathrm{X}^{\mathrm{b}} ; \mathrm{P}=0.80$.

\section{RESULTS AND DISCUSSION}

Higher values for CV\% were found in the Summer-Fall season (S-F) (10.46 to 56.24\%); in the Winter-Spring (W-S), CV\% $=5.20$ to $26.34 \%$ (Table 2). This result was already expected because in S-F, which represents the first semester of the year, there is a situation of very intense environmental variation in the region, concerning temperature and insolation, since water and nutrient are supplied, and the Italian pumpkin shows linear response to temperature and insolation.

The reduction of $\mathrm{CV}(\mathrm{x})$ in both experiments was not linear in relation to the increase of plot size. For smaller plot sizes, the decrease of $\mathrm{CV}(\mathrm{x})$ was more accentuated; for larger sizes, there was a tendency of stability. Therefore, increasing plot size is advantageous up to a given number of plants, for which the use of larger areas is not compensated by the low gains in accuracy. The values of the coefficients of variation for the different planned plots decreased with increasing plots width and/or length. This behavior is accepted as a rule, being conspicuously found in studies on size and shape of plots (Storck, 1979; Oliveira \& Estefanel, 1995; Simplício et al., 1996; Zanon \& Storck, 2000).

Concerning the adjustment of variation coefficient in relation to the size of plot in S-F, it was observed that plots with more than eight plants present low variability reduction (Figure 1). However in Figure 2, which represents the adjustment of variation coefficient in W-S, replicates with more than four plants had low reduction in the variation coefficient. Consequently, by this method, the most adequate size and shape of plots for S-F is eight plants, four in length and two in width; for W-S, four plants, two in length and two in width, is the adequate plot size.

The values of coefficients of variation for the S$\mathrm{F}$ trial were higher as a result of the larger variability in the fruit growth. Such variability was caused, possibly,

Table 2 - Estimates of the variation coefficient in percentage, obtained in replicates of $\mathrm{X} 1$ basic units (BU) of width and X2 BU of length, for the accumulated phytomass value of fruit per plant, in the Italian pumpkin plot crop, cultured in the summer-fall and winter-spring seasons.

\begin{tabular}{lcccccc}
\hline & \multicolumn{3}{c}{ X1 } & - summer-fall & \multicolumn{3}{c}{ X1 } & - winter-spring \\
\cline { 2 - 7 } X2 & 1 & 2 & 4 & 1 & 2 & \multicolumn{1}{c}{4} \\
\hline 1 & 56.24 & 37.78 & 27.23 & 26.34 & 18.85 & 15.35 \\
2 & 37.39 & 25.71 & 18.19 & 18.03 & 12.12 & 8.69 \\
4 & 27.64 & 17.75 & 10.46 & 12.95 & 8.34 & 6.30 \\
5 & 29.24 & 18.24 & 12.29 & 12.40 & 8.73 & 5.20 \\
10 & 22.98 & 17.41 & - & 9.83 & 7.20 & - \\
\hline
\end{tabular}




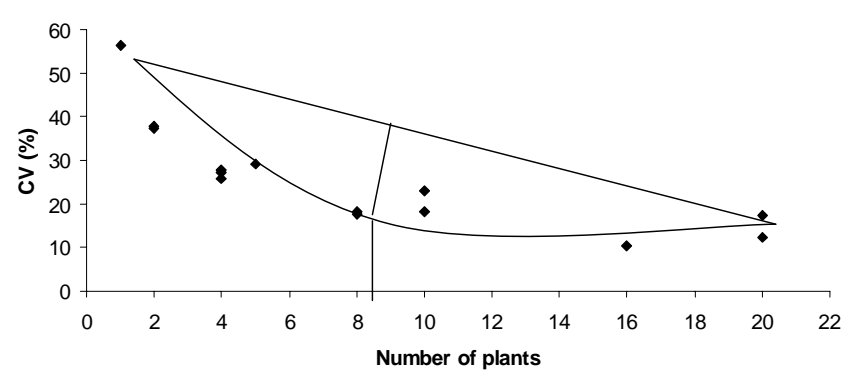

Figure 1 - Relation between the variation coefficient and the size of replicate in number of plants, for the accumulated phytomass of the Italian pumpkin fruit, produced in the Summer - Fall season.

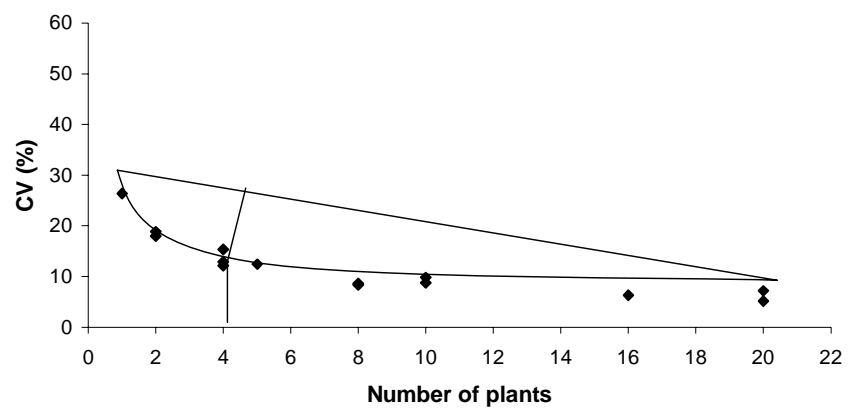

Figure 2 - Relation between the variation coefficient and the size of replicate in number of plants, for the accumulated phytomass of the Italian pumpkin fruit, produced in the Winter - Spring season.

by variations of environmental conditions that occur in this season, such as broader ranges of temperature variation, global solar radiation, cloudiness and relative air humidity. Another important factor regarding S-F is the temperature reduction in the month of May, affecting fruit growth and development, interfering directly in the increase of weight variability of fruit.

By the variance comparison method, all variances reduced to a basic unit, of different sizes and shapes of plots used in the trials, were homogeneous, independently of crop season (Table 3). The ideal plot size for both experiments is the one in which the plot is composed of a basic unit, in other words, one plant.

For the Hatheway method, the estimated values of soil "b" heterogeneity rate and of estimative "a", applied to the formula of minimum significant difference estimate, were respectively 0.74 and $44.63 \%$ for S-F, and 0.97 and $24.63 \%$ for W-S. This shows how heterogeneous the area in this plastic greenhouse is, because the bigger the estimated value of "b", the bigger the soil heterogeneity; in other words, values close to the unit indicate a larger soil heterogeneity and close to nullity, more correlate the adjacent portions will be (Muniz et al., 1999). The result obtained for "b", independently of crop season, favors a large variability in fruit phytomass for this environment, and is explained by the fact that the harvest is done aggressively to the plant, and by doing so, the researcher himself induces a variability source in the experimental area.
Table 3 - Estimative of reduced variances obtained in replicates of X1 basic units (BU) of width, X2 BU of length, $\mathrm{X}=\mathrm{X} 1 * \mathrm{X} 2 \mathrm{BU}$ of size and number of basic units of same size and shape (NUB) for the accumulated value of Italian pumpkin fruit phytomass, cultivated in plastic greenhouses in the summer-fall and winterspring seasons.

\begin{tabular}{crrrcc}
\hline X1 & X2 & X & NUB & Summer-Fall & Winter-Spring \\
\hline 1 & 1 & 1 & 160 & $0.3863^{\text {ns }}$ & $2.2248^{\text {ns }}$ \\
1 & 2 & 2 & 80 & 0.3415 & 2.0853 \\
2 & 1 & 2 & 80 & 0.3486 & 2.2785 \\
1 & 4 & 4 & 40 & 0.3732 & 2.1504 \\
2 & 2 & 4 & 40 & 0.3229 & 1.8859 \\
4 & 1 & 4 & 40 & 0.3621 & 3.0236 \\
1 & 5 & 5 & 32 & 0.5220 & 2.4643 \\
2 & 4 & 8 & 20 & 0.3080 & 1.7843 \\
4 & 2 & 8 & 20 & 0.3233 & 1.9387 \\
1 & 10 & 10 & 16 & 0.6448 & 3.0962 \\
2 & 5 & 10 & 16 & 0.4064 & 2.4438 \\
4 & 4 & 16 & 10 & 0.2137 & 2.0373 \\
2 & 10 & 20 & 8 & 0.7402 & 3.3295 \\
4 & 5 & 20 & 8 & 0.3689 & 1.7368 \\
\hline
\end{tabular}

${ }^{{ }^{n}}$ Non heterogeneous variances, Bartlett test $(\alpha=0.05)$

For fixed values of "a" and d, the size of plot decreases with increasing number of replication and of soil (b) heterogeneity rate; while for fixed "a” and r values, the size of plots decreases with increasing percentile difference between two treatments statistically proven (d) and the "b" rate; finally, for fixed d and $r$ values, it grows with the increase of variation coefficient and "b" rate. Therefore, smaller plots with larger number of replications, allow the detection of smaller percentile differences between treatments, than bigger plots with a smaller number of replications.

From these results, the researcher can establish the size of plot according to the minimum difference between treatments he wishes to detect. An example is shown next (Figures 3 and 4). Minimum difference in percentage of the treatments average of $20 \%$, in the S-F trial (Figure 3), could be detected with four plots of 28 plants (replicates), or eight plots of nine plants (replicates) or, yet 16 plots of four plants (replicates). In the W-S trial (Figure 4), a minimum difference in percentage of average between treatments of $15 \%$ could be obtained trough four plots of six replicates, or with eight plots of three replicates, or yet with 16 plots with two replicates.

Relating the obtained results to the application of the three estimation methods of ideal size and shape of plots, the method of comparison of variances presented an unexpected result, because all the reduced variances, independently of crop season, were homogeneous and, therefore, only one plant became the recommendation of 


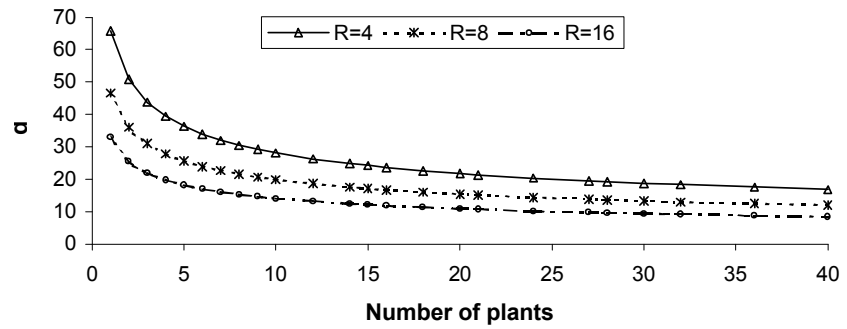

Figure 3 - Difference in percentile of the average (d) to be statistically rejected, for $\mathrm{R}=4,8$ and 16 replications, of the accumulated phytomas of fruit of tte Italian pumpkin produced in the Summer - Fall.

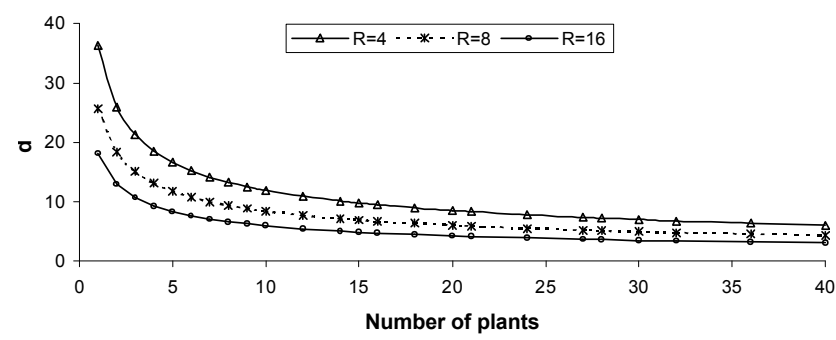

Figure 4 - Difference in percentile of the average (d) to be statistically rejected, for $\mathrm{R}=4,8$ and 16 replications, of the accumulated phytomas of fruit of tte Italian pumpkin produced in the Winter - Spring.

replicate size and shape, but in practice it does not add any advance to experimental planning in these conditions. However, the other methods used provided similar results, in each season, what proves the result obtained, concluding that the maximum curvature method should be preferred for trials run with the same characteristics, because it is a graphic method, with a visual determination of the maximum curvature point, that corresponds to the ideal size and shape of plot, and so becomes more practical and of easier application.

Besides the easiness of the maximum curvature method application, when compared to the Hatheway method, that method does not consider the maximum curvature point dependence of the scale used in the graph construction as well as the size of the smallest basic unit adopted and, it is not rare the good size of replicate being obtained in the gap between two, pre-fixed points by studied sizes and shapes (Viana et al., 2002). Therefore, it is better to use the Hatheway method for estimates and subsequent recommendations of plot size and shape, produced in a plastic greenhouse condition, because besides the maximum curvature method's unfavorable characteristics, the Hatheway method presents conditions to combine different plot sizes and shapes, conciliating different numbers of repetitions, minimum significant differences between two treatments and still consider the soil heterogeneity present in the studied area, in other words, it is a mathematical method which permits many interpretations to support an adequate experiment planning in situations of limited physical area.

\section{ACKNOWLEDGEMENTS}

To "Fundação de Amparo à Pesquisa do Estado do Rio Grande do Sul (FAPERGS)" for granting funds for this research.

\section{REFERENCES}

COCHRAN, W.G.; COX, G.M. Experimental designs. 6.ed. New York: Wiley \& Sons, 1968. 616p.

GOMES, F.P. O problema do tamanho de parcelas em experimentos com plantas arbóreas. Pesquisa Agropecuária Brasileira, v.19, p.1507-1512, 1984.

HATHEWAY, W.H. Convenient plot size. Agronomy Journal, v.53, p.279-280, 1961.

HATHEWAY, W.H.; WILLIAMS, E.J. Efficient estimation of the relationship between plot size and the variability of crop yields. Biometrics, v.14, p.207-222, 1958.

LESSMAN, K.J.; ATKINS R.E. Optimum plot size and relative efficiency of lattice designs for grain sorghum yield tests. Crop Science, v.3, p.477-481, 1963.

LOPES, S.J.; STORCK, L.; HELDWEIN, A.B.; FEIJÓ, S.; DA ROS, C.A. Técnicas experimentais para tomateiro tipo salada sob estufas plásticas. Ciência Rural, v.28, p.193-197, 1998.

MUNIZ, J.A.; SIMPLÍCIO, E.; AQUINO, J.H.; SOARES, A.R. Determinação do tamanho de parcelas experimentais em povoamento de Eucaliptus grandis Hill. II - parcelas quadradas. Ciência e Agrotecnologia, v.23, p.446-453, 1999.

OLIVEIRA, P.H.; ESTEFANEL, V. Tamanho e forma da parcela para avaliação do rendimento em experimentos com batata. Ciência Rural, v.25, p.20-220, 1995.

ORTIZ, R. Plot techniques for assessment of bunch weight in banana trials under two systems of crop management. Agronomy Journal, v.87, p.63-69, 1995.

RESENDE, M.D.V.; SOUZA JR., C.L. Número de repetições e tamanho da parcela para seleção de progênies de milho em solos sob cerrado e fértil. Pesquisa Agropecuária Brasileira, v.32, p.1457-1461, 1997.

SIMPlíCIO, E.; MUNIZ, J.A.; AQUINO, L.H.; SOARES, A.R. Determinação do tamanho de parcelas experimentais em povoamentos de Eucalyptus grandis Hill ex-Maiden. I - Parcelas retangulares. Cerne, v.2, p.53-65, 1996.

SMITH, H.F. An empirical law describing heterogeneity in the yields of agricultural crops. Journal of Agricultural Science, v.28, p.1-23, 1938.

STEEL, R.G.D.; TORRIE, J.H.; DICKEY, D.A. Principles and procedures of statistics: a biometrical approach. 3.ed. New York: McGraw-Hill, 1997. 666p.

STORCK, L. Estimativa para tamanho e forma de parcela e número de repetições para experimentos com milho (Zea mays L.) Porto Alegre: UFRGS, 1979. 98p. (Dissertação - Mestrado).

STORCK, L.; UITDEWILLIGEN, W.P.M. Estimativa para tamanho e forma de parcela e número de repetições para experimentos com milho (Zea mays L.) Agronomia Sulriograndense, v.16, p.269-282, 1980.

STORCK, L.; SACCOL, A.V.; SCHNEIDER, F.M. Comparação de métodos de estimativa do índice de heterogeneidade do solo e do tamanho ótimo de parcela em experimento com soja. Ciência Rural, v.12, p.189-202, 1982.

VALLEJO, R.L.; MENDOZA, H.A. Plot technique studies on sweet potato yield trials. Journal of the American Society for Horticultural Science, v.117, p.508-511, 1992.

VIANA, A.E.S.; SEDIYAMA, T.; CECON, P.R.; LOPES, S.C.; SEDIYAMA, M.A.N. Estimativas de tamanho de parcelas em experimentos com mandioca. Horticultura Brasileira, v.20, p.58-63, 2002.

ZANON, M.L.B.; STORCK, L. Tamanho ótimo de parcelas experimentais para Eucalyptus saligna Smith em dois estádios de desenvolvimento. Cerne, v.6, p.104-111, 2000.

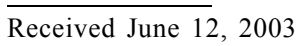

Accepted April 28, 2004 